УДК 342.9

DOI: https://doi.org/10.54929/pmtl-issue2-2021-07

\title{
АДМІНІСТРАТИВНІ СТЯГНЕННЯ В СФЕРІ ЗАБЕЗПЕЧЕННЯ БЕЗПЕКИ ДОРОЖНЬОГО РУХУ: РЕАЛІЇ ТА ПЕРСПЕКТИВИ СУЧАСНОЇ ДОКТРИНИ
}

\section{ADMINISTRATIVE PENALTIES IN THE FIELD OF ROAD SAFETY: THE REALITIES AND PROSPECTS OF MODERN DOCTRINE}

\author{
Доненко В. В. \\ доктор юридичних наук, доцент, \\ профресор кафедри адміністративного та митного права \\ Університет митної справи та фрінансів \\ ORCID: 0000-0002-5817-1406 \\ Valerii Donenko \\ Doctor of Law, Associate Professor, \\ Professor of the Department of Administrative and Customs Law \\ University of Customs and Finance
}

У статті досліджується проблема адміністративної відповідальності у сфері забезпечення безпеки дорожнього руху в Україні на процес розвитку доктрини адміністративно-деліктного права. Розглянуто основні види адміністративних стягнень, які застосовуються за порушення правил дорожнього руху. Детально проаналізовано стан розвиток адміністративної відповідальності за період незалежності України. Зазначено про недоречність скасування штрафних балів. Запропоновано перспективні тенденції розвитку доктрини адміністративної відповідальності в сфрері забезпечення безпеки дорожнього руху. Автором встановлено, що транссормація адміністративної відповідальності обумовлює необхідність перегляду існуючих адміністративних стягнень, як складової адміністративного примусу. В иій статті обгрунтовано наступні перспективні напрямки розвитку доктрини адміністративної відповідальності: узагальнення уявлень про систему елементів адміністративного примусу в сфрері забезпечення безпеки дорожнього руху; розвиток доктрини складових адміністративного примусу; удосконалення теоретичних положень щодо змісту адміністративного примусу в цілому та розширення його складової через впровадження нових елементів, які фактично існують у адміністративно-деліктному законодавстві, але не отримали належної наукової оцінки. Ключові слова: адміністративна відповідальність, безпека дорожнього руху, адміністративний примус, адміністративні стягнення, додаткові (позасанкційні) заходи впливу, пов'язанні з вчиненим адміністративним правопорушенням.

В статье исследуются проблемы административной ответственности в сфере обеспечения безопасности дорожного движения в Украине на процес развития доктрины административно-деликтного права. Рассматриваются основные виды административных взысканий, которые применяются за нарушение правил дорожного движения. Детально проанализировано состояние развития административной ответственности за период независимости Украины в этой сфрере. Указывается про необоснованность упразднения итрафрных балов. Предложены перспективные тенденции развития доктрины административной ответственности в сфрере обеспечения безопасности дорожного движения. Автором констатируется, что трансформация административной ответственности обуславливает необходимость пересмотра существующих административных взысканий, как составной административного принуждения. В статье обосновывается перспективные направления развития доктрины административной ответственности: обобщение представлений о системе элементов административного принуждения в сфрере обеспечения безопасности дорожного движения; развитие доктрины составляющих административного принуждения; усовершенствование теоретических положений содержания административного принуждения в целом и расширение их составляющей через внедрение новых элементов, фрактически существующих в административно-деликтном законодательстве, но не получивших надлежащей научной оценки. Ключевые слова: административная ответственность, безопасность дорожного движения, административное принуждение, административные взыскания, дополнительные (внесанкионные) меры принуждения, связанные с совершенным административным правонарушением.

The article examines the problem of administrative liability in the field of road safety in Ukraine for the development of the doctrine of administrative tort law. The main types of administrative penalties applied for violation of traffic rules are considered. The state of development of administrative responsibility for the period of independence of Ukraine is analyzed in detail. It is noted that it is inappropriate to cancel penalty points. Prospective trends in the development of the doctrine of administrative responsibility in the field of road safety are proposed. The author finds that the 
transformation of administrative responsibility necessitates the revision of existing administrative penalties as part of administrative coercion. This article substantiates the following promising areas of development of the doctrine of administrative responsibility: generalization of ideas about the system of elements of administrative coercion in the field of road safety; development of the doctrine of the components of administrative coercion; improving the theoretical provisions on the content of administrative coercion in general and expanding its component through the introduction of new elements that actually exist in administrative tort law, but have not received a proper scientific assessment. It is established that the existing resource of administrative penalties requires a new approach to their application, a scientific justification for expanding the possibilities of their application. Requires scientific substantiation of the existing possibilities of additional (non-sanctioning) influence (obligatory passing of extraordinary medical examination and passing of theoretical and practical examinations on knowledge of traffic rules, etc.) and development and implementation of special programs. The list of these tools is not limited to those proposed. Key words: administrative responsibility, road safety, administrative coercion, administrative penalties, additional (extra-bank) coercive measures related to the committed administrative offense.

Постановка проблеми. Соціально-політичні зміни в Україні та нові пріоритети державотворення, в основу яких покладено примат забезпечення прав і свобод людини і суспільства в цілому, стимулюють вітчизняну юридичну науку до пошуку нових форм забезпечення потреб суспільства правовими засобами. Одним із наріжних шляхів активізації процесу переходу від застарілих і архаїчних дослідницьких моделей до інноваційних є створення нової наукової адміністративно-правової доктрини, яка б враховувала принципові зміни у погляді на суспільне призначення адміністративного права, розуміння його як права забезпечення і захисту прав людини [1, с. 6] Складна ситуація на автошляхах проявляється в тому, що кожні 3 хвилини трапляється дорожньо-транспортна пригоди, у яких кожні 15 хвилин травмувалася особа, а кожні 3 години гинула. В цілому в Україні у 2020 році було скоєно 168 тис. дорожньо-транспортних пригод [2].

Тому з аналіз чинного законодавства в сфері забезпечення безпеки дорожнього руху, а також практика його застосування свідчать про необхідність його удосконалення через переосмислення значення інституту адміністративної відповідальності за порушення правил дорожнього руху.

Аналіз останніх досліджень і публікацій. Процесам дослідження деліктних проблем адміністративного права присвячені фундаментальні праці О. М. Бандурки, В.М.Бевзенка, І. П. Голосніченко, С. Т. Гончарука, Є. В. Додіна, В. К. Колпакова, Т. О. Коломоєць, А. Т. Комзюка, М. М. Тищенка, О. В. Кузьменко, О. І. Миколенко, Р. С. Мельника, Д. М. Лук'янця, П. С. Лютікова, В. К. Шкарупа. Стосовно праць, присвячених забезпеченню безпеки дорожнього руху, ключові дослідження здійснили Т. О. Гуржій, В.В.Донський, В.В.Гаркуша, В.А. Мисливий, В.В. Новиков, О. Ю. Салманова, В. О. Собакарь, В.Й. Развадовський та інші. За роки незалежності в Україні створено відповідну нормативну базу та організаційну структуру, з моменту їх прийняття здійснювалися спроби законодавця як лібералізувати, так і посилити адміністративну відповідальність за порушення у цій сфрері, однак суттєвих позитивних зрушень це не дало. Слід наголосити, що всі здійснені дослідження створили існуючу парадигму адміністративної відповідальності в сфрері забезпечення безпеки дорожнього руху як складової адміністративного примусу [3, с. 67-69].

Виділення невирішених раніше частин загальної проблеми, котрим присвячується означена стаття. Збільшення кількості транспортних засобів та порушень правил дорожнього руху, і як наслідок, зростання кількості дорожньотранспортних пригод отримує відповідну реакцію держави у посиленні адміністративної відповідальності у вигляді збільшення розміру штрафрів в цій сорері. Спроби запропонувати новий вид стягнення- штрафні бали, через п'ять років після їх впровадження, без практичної реалізації, призвели до їх виключення взагалі. Головним ресурсом впливу на безпеку дорожнього руху, залишається посилення розмірів штрафу на законодавчому рівні, практичній діяльності та існуючій доктрині в цій сорері. Проте існують непрямі важелі впливу поза існуючими стягненнями, яким вітчизняне українське адміністративно-правова наука не дала окремої класифікації, попре їх існування у чинному законодавстві та успішне використання у міжнародній практиці, вартих уваги і для вітчизняного досвіду. В тому чи іншому вигляді такі важелі впливу існували (наприклад, обов'язок повторно скласти іспит на знання правил дорожнього руху, пройти повторне медичне обстеження, заходи впливу, які застосовуються до неповнолітніх та інші), але їх окремого визначення, класифрікації не відбулося, проте має значно більший вплив ніж саме стягнення чи його розмір, хоча застосовується після накладення адміністративного стягнення. Зазначені важелі впливу не підпадають у класичне сприйняття адміністративного примус та його класифрікацію (попередження, припинення, адміністративні стягнення), але, на наш погляд, мають пряме відношення до адміністративних стягнень. Вірніше, до результатів їх застосування.

Формулювання цілей статті (постановка завдання). Метою статті є комплексний теоретико-правовий аналіз доктрини адміністративних стягнень, як складової публічного примусу 
на фоні процесу розвитку нових явищ, які потребують відповідної наукової оцінки.

Виклад основного матеріалу дослідження. Чинні адміністративні стягнення за правопорушення в сорері забезпечення безпеки дорожнього руху передбачені Кодексом України про адміністративні правопорушення відповідно до якого можуть застосовуватись такі адміністративні стягнення: попередження; штраф; оплатне вилучення предмета, який став знаряддям вчинення або безпосереднім об'єктом адміністративного правопорушення - оплатне вилучення транспортного засобу; конфіскація: предмета, який став знаряддям вчинення або безпосереднім об'єктом адміністративного правопорушення; позбавлення спеціального права, наданого даному громадянинові - права керування транспортними засобами, адміністративний арешт.

3 урахуванням того, що найбільш небезпечні правопорушення розглядаються місцевими загальними судами, звернемо увагу на результати судової практики за 2020 рік. Упродовж 2020 р. на розгляді місцевих загальних судів перебувало 335 тис. (309 тис.) справ про порушення Правил дорожнього руху (далі - Правила), що на 8,3\% більше порівняно з 2019 р.; їх частка від загальної кількості справ про адміністративні правопорушення, що перебували на розгляді місцевих загальних судів, також збільшилась і становила $39,7 \%(37,1 \%)$ [4].

Зокрема, на підтвердження попередньої тези у структурі всіх справ про адміністративні правопорушення, що надійшли на розгляд до місцевих загальних судів, найбільшу частку становили: 1) справи про порушення правил дорожнього руху, що спричинило пошкодження транспортних засобів, вантажу, автомобільних доріг, вулиць, залізничних переїздів, дорожніх споруд чи іншого майна -ДТП (ст. 124 КУпАП),-17,1\% (19\%) від усіх справ про адміністративні правопорушення, що надійшли на розгляд, або 144 тис. таких справ та 2) справи про вчинення правопорушень, пов'язаних із керування транспортними засобами або суднами особами, які перебувають у стані алкогольного, наркотичного чи іншого сп'яніння або під впливом лікарських препаратів, що знижують їх увагу та швидкість реакції (ст. 130 КУпАП) - 16,3\% (17,4\%), або 138 тис. справ [4].

За порушення Правил дорожнього руху місцеві загальні суди застосували різні види стягнень до 210 тис. (192 тис.) правопорушників, або $48,5 \%(47,3 \%)$ від усіх осіб, на яких накладено адміністративне стягнення. Найпоширенішим видом серед адміністративних стягнень, застосованих до осіб за порушення Правил дорожнього руху, був штраф. Так, у 2020 р. оштрафовано 206 тис. (189 тис.) осіб, що на 9\% більше; проте їх частка від кількості всіх осіб, на яких накладено адміністративне стягнення за порушення Правил, залишилася майже на рівні попереднього року - 98,1\% (98,2\%). Загальна сума накладеного штрафу становила 1 млрд. 138 млн. 750 тис. грн (944 млн. 241 тис. Грн), із яких добровільно сплачено 180 млн. 63 тис. грн, або 15,8\% (18,2\%) від суми накладеного. Позбавлення права керування транспортними засобами (як основний, так і додатковий вид адміністративного стягнення) за грубе або повторне, або за систематичне порушення порядку користування цим правом застосовано до 74 тис. (66 тис.) осіб, або 35,4\% (34,5\%) від тих осіб, на яких накладено адміністративне стягнення за порушення Правил дорожнього руху. Зазначене свідчить про достатню ефективність таких видів адміністративних стягнень як штраф та позбавлення права керування транспортними засобами. В той час, слід константувати про недостатньє використання ресурс адміністративного арешту, оплатного вилучення транспортного засобу та попередження. Так, адміністративний арешт за порушення Правил дорожнього руху призначено 206 (293) особам, або 0,1\% (0,2\%), а оплатне вилучення транспортного засобу у його власника застосовано до 225 (173) осіб, що більше на 30,1\% порівняно з 2019 р. Попередження винесено тільки 60 (21) особам (більше у 2,9 рази) [4].

3 огляду на вищенаведене, слід звернути на наступні обумовленості розвитку доктрини адміністративної відповідальності.

По-перше, Кодекс України про адміністративну відповідальність несе в собі ресурс неіснуючої держави з 1984 року і має бути змінений з урахуванням вимог сьогодення, розвитку доктрини адміністративного права; по-друге, всі зміни та доповнення, які наразі вносяться мають здійснюватися з можливістю їх застосування у новому кодифікованому акті; по-третє, скасування штрафних балів як складової автоматичної фріксації порушень правил дорожньої руху є помилкою, яка обумовлена з одного боку відсутністю єдиної концепції розвитку адміністративно-деліктного законодавства, а з іншого продовженням суто каральної політики держави щодо порушників правил дорожнього руху [5, с. 119-121]; по-четверте, окремої уваги заслуговує вивчення ефективності застосування: а) попередження (винесено 60 особам) (яке застосовується фактично як виключення за інші порушення правил дорожнього руху (ст. 125 КУпАП), б) оплатного вилучення транспортного засобу (225) та адміністративно арешту (206) на фоні тільки 168 тисяч дорожньо-транспортних пригод; по-п'яте, має запроваджуватися додатковий потенціал можливого впливу за вчинення окремих порушень у сорері забезпечення дорожнього руху. Існуючі в чинному законодавстві додаткові засоби впливу не знайшли належної наукової підтримки, 
а сучасний їх розвиток стимулює до розвитку їх наукового підґрунтя.

Наприклад, нововведена стаття 317-1 КУпАП «Порядок виконання постанови про позбавлення права керування транспортним засобом» \{Кодекс доповнено згідно із Законом № 1231-ІХ від 16.02.2021) [7] містить положення за якими після закінчення строку позбавлення права керування транспортним засобом посвідчення водія повертається в порядку, визначеному Кабінетом Міністрів України. Відповідно до якого повернення посвідчень водія особам, позбавленим права на керування транспортними засобами здійснюється після складення теоретичного і практичного іспитів, а особам, позбавленим права на керування транспортними засобами за керування такими засобами у стані алкогольного, наркотичного чи іншого сп'яніння або під впливом лікарських препаратів, що знижують увагу та швидкість реакції, посвідчення водія повертається після обов'язкового проходження позачергового медичного огляду та складення теоретичного і практичного іспитів. Повернення посвідчення водія, отриманого вперше, особі, позбавленій права на керування транспортними засобами не здійснюється. У такому випадку після набрання чинності рішенням суду про позбавлення особи права на керування транспортними засобами посвідчення водія вважається недійсним, підлягає вилученню та передається для знищення до територіального сервісного центру MBC за місцем проживання особи, зазначеним у цьому рішенні. Для отримання права на керування транспортними засобами така особа після закінчення строку, на який її позбавлено такого права, проходить позачерговий медичний огляд, повторну підготовку в закладі та складає теоретичний і практичний іспити у територіальному сервісному центрі MBC, після чого отримує посвідчення водія, яке вважається отриманим вперше. 3 наведеного слід зробити висновок, що особа, яка була позбавлена права на керування транспортним засобом, додатково після відбуття відповідного терміну, отримує додаткові несприятливі для себе наслідки. Тобто міра відповідальності у вигляді конкретного виду адміністративного стягнення, яка застосовується до особи за вчинене правопорушення, з метою виховання особи, яка вчинила адміністративне правопорушення, в дусі додержання законів України, поваги до правил співжиття, а також запобігання нових правопорушень як самим правопорушником, так і іншими особами. (ст 23 КУпАП) не обмежується межами адміністративної санкції. На наш погляд, обов'язкове проходження позачергового медичного огляду та складення теоретичного і практичного іспитів, становить важливу складову, додатково посилює міру відповідальності та підвищує ефект іï застосування.
На жаль, ця процедура в Україні має формальний характер з різних причин, високі корупційні ризики. Доречно звернутися до досвіду Федеративної Республіки Німеччина в якій існує порядок до осіб, які керували транспортним засобом у стані алкогольного чи наркотичного сп'яніння, систематично порушували правила дорожнього руху та інші призначають медико-психологічне обстеження (MPU) як перевірку здатності до керування транспортними засобами. За статистикою, категорії осіб, які складають MPU, розподіляються таким чином, 34\% - особи, які керували транспортним засобом у стані алкогольного сп'яніння, $24 \%$ - повторне керування у стані алкогольного сп'яніння, 18\% наркотичного сп'яніння, 30\% - інші випадки.

Самі громадяни цю перевірку називають «тест для ідіотів» («Idiotentest»). Причому сам тест вартує від 400 до 800 євро, в залежності від виду вчиненого порушення правил дорожнього руху. До того, додатково порушники мають сплатити психологу, у якого мають пройти відповідний курс, в більшості випадків особи мають користуватися послугами по підготовці для складення іспиту.

Іншим прикладом засобів впливу $є$ новели, передбачені стаття 265-4 КУпАП [7] регламентується тимчасове затримання транспортних засобів інспекторами з паркування здійснюється шляхом доставки для зберігання на спеціальний майданчик чи стоянку за допомогою спеціального автомобіля - евакуатора і дозволяється виключно у випадках, встановлених цією статтею.

Повернення транспортного засобу, затриманого шляхом доставки для зберігання на спеціальний майданчик чи стоянку, відбувається невідкладно за зверненням такої після сплати штрафу за вчинене правопорушення та оплати вартості послуг із транспортування та/або зберігання транспортного засобу. Не вдаючись до детального аналізу норм цієї статті, лише зазначимо що вартість послуг спеціального автомобіля-евакуатора майже у всіх випадках його застосування, перевищує розмір штрафу передбаченого статтею 152-1. КУпАП Порушення правил паркування транспортних засобів та порушення правил обладнання майданчиків для платного паркування транспортних засобів, а відтак має значно більший привентивний вплив на порушника, маючи фінансово невигідну позицію для порушника цих правил.

Іншим існуючим заходом впливу, пов'язаного з накладенням стягнення за адміністративне правопорушення, поза межами сфери забезпечення безпеки дорожнього руху, є положення статті 39-1 КУпАП Направлення на проходження програм для особи, яка вчинила домашнє насильство чи насильство за ознакою статі У разі вчинення домашнього насильства чи насильства за ознакою статі суд під час вирішення питання про накла- 
дення стягнення за адміністративне правопорушення має право одночасно вирішити питання про направлення особи, яка вчинила домашнє насильство чи насильство за ознакою статі, на проходження програми для таких осіб, передбаченої Законом України «Про запобігання та протидію домашньому насильству» чи Законом України «Про забезпечення рівних прав та можливостей жінок і чоловіків» [7]. Аналогічні програми слід розробити та застосовувати до окремих злісних порушників правил дорожнього руху.

Висновки з цього дослідження. Дослідження особливостей розвитку доктрини адміністративної відповідальності в сфері забезпечення безпеки дорожнього руху дозволяє зазначити наступне:

1. Встановлено, що існуючий ресурс адміністративних стягнень потребує нового підходу до їх застосування, наукового обґрунтування розширення можливостей їх застосування.

2. Потребує наукового обґрунтування існуючі можливостей додаткового (позасанкційного) впливу (обов'язкове проходження позачергового медичного огляду та складення теоретичного і практичного іспитів на знання правил дорожнього руху тощо) та розробка і впровадження проходження спеціальних програм. Перелік цих засобів не обмежується запропонованим.

3. Пропонується внесення до чинного КУпАП статті 39-2 в наступній редакції «У разі вчинення керування транспортними засобами за керування такими засобами у стані алкогольного, наркотичного чи іншого сп'яніння або під впливом лікарських препаратів, що знижують увагу та швидкість реакції, суд під час вирішення питання про накладення стягнення за адміністративне правопорушення має право одночасно вирішити питання про направлення особи, яка вчинила таке правопорушення, на проходження програми для таких осіб у відповідності до чинного законодавства, а посвідчення водія повертається після обов'язкового проходження позачергового медичного огляду та складення теоретичного і практичного іспитів.

\section{БІБЛІОГРАФІЧНИЙ СПИСОК:}

1. Виконавча влада і адміністративне право/ За заг. ред. В.Б. Авер'янова. Київ : Видавничий Дім «Ін-Юре», 2002. $668 \mathrm{c}$.

2. Звіт Національної поліції України про результати роботи у 2020 році. URL:https://www.kmu.gov.ua/storage/ app/sites/1/17-civik-2018/zvit2020/npu-zvit-2020.

3. Велика українська юридична енціклопедія : у 20 т Т. 5 Адміністративне право/редкол.: Ю.П. Битяк та ін.; Нац. акад.прав.наук України; Ін-т держави і права ім. В.М. Корецького НАН України; Нац. юрид.ун-т ім. Ярослава Мудрого.-2020. 960 с.

4. Аналіз стану здійснення правосуддя у кримінальних провадженнях та справах про адміністративні правопорушення у 2020 році URL:https://supreme.court.gov.ua/userfiles/media/new_folder_for_uploads/supreme/ Analiz\%20statistika\%20(kriminal)\%202020.

5. Статистичний звіт ДСА форми № 1-п «Звіт судів першої інстанції щодо розгляду справ про адміністративні правопорушення». URL:https://court.gov.ua/inshe/sudova_statystyka/rik_2020

6. Доненко В.В. Становлення публічного адміністрування в сфері безпеки дорожнього руху: до питання скасування штрафних балів. Порівняльно-аналітичне право. 2020. № 2. С. 119-121.

7. Кодекс України про адміністративні правопорушення від 7.12.1984 № 8074-10. Відомості Верховної Ради Української РСР. 1985. №17. Ст. 415.

\section{REFERENCES:}

1. Aver'janova, V.B. e.d. (2002). Vykonavcha vlada i administratyvne pravo/ Za zag. red. Kyiv. (in Ukrainian).

2. Zvit Nacional'noi' policii' Ukrai'ny pro rezul'taty roboty u 2020 roci. URL:https://www.kmu.gov.ua/storage/app/ sites/1/17-civik-2018/zvit2020/npu-zvit-2020. (in Ukrainian).

3. Velyka ukrai'ns'ka jurydychna enciklopedija (2020).: u 20 t T. 5 Administratyvne pravo/redkol.: Ju.P. Bytjak ta in.; Nac. akad.prav.nauk Ukrai'ny; In-t derzhavy i prava im. V.M. Korec'kogo NAN Ukrai'ny; Nac. juryd.un-t im. Jaroslava Mudrogo. (in Ukrainian).

4. Analiz stanu zdijsnennja pravosuddja u kryminal'nyh provadzhennjah ta spravah pro administratyvni pravoporushennja u 2020 roci URL:https://supreme.court.gov.ua/userfiles/media/new_folder_for_uploads/supreme/ Analiz\%20statistika\%20(kriminal)\%202020. (in Ukrainian).

5. Statystychnyj zvit DSA formy № 1-p «Zvit sudiv pershoi' instancii' shhodo rozgljadu sprav pro administratyvni pravoporushennja». URL:https://court.gov.ua/inshe/sudova_statystyka/rik_2020. (in Ukrainian).

6. Donenko, V.V. (2020). Stanovlennja publichnogo administruvannja v sferi bezpeky dorozhn'ogo ruhu: do pytannja skasuvannja shtrafnyh baliv. Porivnjal'no-analitychne pravo. № 2. S. 119-121.

7. Kodeks Ukrai'ny pro administratyvni pravoporushennja vid 7.12.1984 № 8074-10. Vidomosti Verhovnoi' Rady Ukrai'ns'koi' RSR. 1985. № 17. St. 415. 